\title{
Export Product Quality between China and Asian Countries
}

\author{
Mastooreh Eshraghi • Normaz Wana Ismail
}

Published online: 5 December 2012

(C) CEEUN 2012

\begin{abstract}
This study aims to measure the export product quality improvement for trade between China and five selected Asian countries namely, India, Malaysia, Thailand, the Philippines and Indonesia using product quality value method of Azhar and Elliott (Rev World Econ 139(3):419-439, 2006). Vertical intra-industry trade high is considered as high quality products. We examined disaggregated four-digit standard international trade classification data, for the period of 2000 to 2008. The results propose that Malaysia has the highest benefits of intra-Industry trade with China while, Philippines and India are in second and third places. Export product quality improvement of Thailand is clearly evident in the second period, where with $87.88 \%$ growth of high quality product can be a prospective partner choice in trading for China. It is worth for China to focus on Thailand as a significant importer on high quality products.
\end{abstract}

Keywords Export quality $\cdot$ China $\cdot$ Product quality value $\cdot$ Intra-industry trade

\section{Introduction}

Traditional trade theory explains that the occurrence of trade is based on differences in productivity and factor endowment while Linder hypothesis focuses more on taste similarity. Empirically, literatures on trade models have shown that determinants of trade include market size, transaction costs, common borders,

\footnotetext{
M. Eshraghi

School of Graduate Studies, University Putra Malaysia, Serdang, Malaysia

e-mail: e_mastoreh@yahoo.co.uk
}

N. W. Ismail $(\bowtie)$

Department of Economics, Faculty of Economics and Management,

University Putra Malaysia, Serdang, Selangor, Malaysia

e-mail: nwi@putra.upm.edu.my; drnormazismail@gmail.com 
common language, and free trade agreement. While free trade agreements are found to significantly reduce trade costs and encourage trade, the difference between types of product causes some countries to become more selective in buying only the high quality and value added products. Helble and Okubo (2008) examined the role of quality in trade among similar economies. They found that quality has a major role in influencing international trade of developed countries and larger economies tend to have higher export quality compared to smaller economies. However, the critical issues in the literature include the measurement of product quality, where it is difficult to quantify the quality of a product. In another study, Azhar and Elliott (2006) proposed product quality value (PQV) as a way to measure product quality in vertical intra industry. Devadason (2008a, b) showed the evidence of export quality from China to the rest of the world for the period of 1992 to 2008. This study aims to provide recent evidence on export product quality from China, focusing on five developing countries, for the period of 2000 to 2008. The countries involved in this analysis are India, Malaysia, Thailand, Indonesia and the Philippines.

The significance of China in world trade has obtained high attention over the last two decades. As the largest economy that has the fastest growth among developing countries, China was the world's top exporter in 2009 and the largest country of world in terms of population size, with a market size bigger than the EU. Alvarez and Claro (2007) found the development in quality of Chinese products as an important factor of Chinese export growth. Meanwhile, Devadason (2008a, b) mentioned that the higher shares in the world trade and improvements in product quality place China in a better situation than other Asian developing countries, in terms of influencing global trade. Thus, it is important to study export quality in trade between China and developing countries focusing on trade in manufactures.

\section{Literature Review}

The earliest theoretical work on quality and trade dates back to Linder (1961). Linder's country similarity theory hypothesizes that nations with similar demands would develop similar industries. In other words, countries with similar per capita income levels trade more with each other. Alchian and Allen (1964) developed a new hypothesis, "when the prices of two substitute goods, such as high and low grades of the same product, are both increased by a fixed per-unit amount such as a transportation cost or a lump-sum tax, consumption will shift toward the highergrade product. This is true because the added per-unit amount decreases the relative price of the higher-grade product". ${ }^{1}$

The most prominent contributions of supply side theoretical work on quality are Falvey (1981), Flam and Helpman (1987), and Falvey and Kierzkowski (1987), who introduced the vertical differentiation model. Falvey (1981) and Falvey and Kierzkowski (1987) proposed a Heckscher-Ohlin based explanation for quality production. They found that most countries specialize in the production of a good which intensively uses its abundant factors. Moreover, Falvey and

\footnotetext{
${ }^{1}$ Alchian-Allen Theory.
} 
Kierzkowski (1987) found that a product is traded according to technology differences along the Ricardian lines whereas Flam and Helpman (1987) used a Ricardian type method to model quality trade. Both studies concluded that quality depends not on the amount of capital used in production, but on technology. They showed that countries that have a comparative advantage in high quality products export high quality products and import low quality commodities.

Romalis (2004) analysed predictions of the factor proportions model in commodity markets. He studied how factor proportions determine the structure of product trade. His findings show that countries get larger shares of world production and trade for goods that use their abundant factors more intensively. Hallak (2006) constructed a theoretical framework for presenting evidence on the relationship between export quality and income per capita of the importer country. His results support the forecasted significant role of product quality as a determinant of the direction of trade. Feenstra and Romalis (2006), Romalis (2004) and Feenstra (2004), used a Heckscher-Ohlin framework with a range of industries, each with differentiated products produced under monopolistic competition.

The second group of literature on export quality focuses on the differences of the demand side among countries. Stockey (1991) found that consumers in rich countries consume more of the same good than consumers in poor countries. Murphy and Shleifer (1997) created a Ricardian model based on testing differences between countries, where results show that high quality producing countries have a consumption preference for high quality goods as low quality producing countries for low quality goods, hence discouraging trade between the two.

Many empirical studies examined the role of quality in describing international trade pattern. For example, Schott (2004) used product level US import data and found that countries like to specialize within products and not across products. He concluded that high income countries with higher unit value use their endowment advantage to add quality to their products, which are different than the products of low income countries. Hummels and Skiba (2004) have tested the Alchian and Allen hypothesis and extended their theory by deriving a relationship between per unit and ad valorem trade costs and the quality composition of trade. Hummels and Klemow (2005) examined the extent to which larger economies export higher volumes of each good or the intensive margin, export a wider set of goods or the extensive margin and export higher quality goods. They argued that large economies export more than small economies, and richer countries export higher amounts at higher quality.

Hallak (2006) developed an empirical framework by focusing on demand side. He measured the effect of quality on bilateral trade flows in order to estimate the role of product quality, as a determinant of international trade. As a conclusion, he found that rich countries tend to import more from countries that produce high quality products. Hallak and Schott (2008) estimated export product quality using a method for separating price and quality difference in unit value data over time and across countries. They discovered that the level of quality was correlated with the level of development. Helble and Okubo (2008) expanded a theoretical model on quality in a heterogeneous quality firms' framework using a gravity type model. They found that higher quality products are not only exported more but they are 
possibly traded farther. They concluded that larger economies have more export qualities, on average, relative to smaller economies and higher quality goods are traded with increasing trade costs. Khandelwal (2010) investigated the relationship between the level of development in the exporting countries and export quality. As he analysed price and quality, he found that the challenging nature of United States manufacturers are to experience competition from imports. A more recent study on product quality in trade is Devadason (2008a, b), who followed Azhar and Elliott (2006) in differentiating between horizontal and vertical intra-industry trade flows. Comparing the product quality changes, Devadason showed the dispersion of product quality in intra-industry trade flows and supported the preference theory to explain the improvement of product quality.

\section{Analytical Framework and Technique}

This study adopted a method used by Devadason (2008a, b), which is based on methodology of Azhar and Elliott (2003, 2006). This approach analyses quality differentiated trade patterns for any type of goods, during any period of years and in various industries, to measure the share of product quality in vertical or horizontal intra-industry trade.

It is a two-stage approach to measure product quality changes. In the first stage, the $S$ index is used to measure dynamic intra-industry trade or to measure products that may have experienced large increase or decrease in matched trade during the time of analysis. Thus, the $\mathrm{S}$ index is as follows:

$$
S=\frac{1}{2 L}(\Delta X-\Delta M)=\frac{\Delta X-\Delta M}{2(\max \{|\Delta X| t,|\Delta M| t\})}, \quad \text { for } t \in N, N=\{1,2,3, \ldots, n\}
$$

In stage two, we used the $S$ index in the range of $(-0.4<S<0.4)$ to calculate PQV index. The PQV index is a measure of the dispersion of product quality in intra-industry trade flows. The PQV is given as:

$$
P Q V=1+\frac{\left(U V^{X}-U V^{M}\right)}{\left(U V^{X}+U V^{M}\right)} \quad \text { with } 0<\mathrm{PQV}<2
$$

where, unit value (UV) is a proxy for quality, UVM is unit value of import and UVX is unit value of export. If export and import share as a minimum of $85 \%$ of their costs, products are defined as horizontal intra-industry trade. Therefore, the PQV index is one if every two-way trade is same in quality and vertical intra-industry trade is equal to zero $(\mathrm{PQV}=1$ if VIIT $=0)$. We use an interval of $(0.85-1.15)^{2}$ to find whether index of PQV is suitably far from one, to specify quality differences. Thus, the range of horizontal intra-industry trade (HIIT) is as follow:

$$
0.85 \leq \mathrm{PQV} \leq 1.15, \quad \text { HIIT } .
$$

\footnotetext{
${ }^{2}$ See Fontagné and Freudenberg (1997), Greenaway et al. (1994), Chiarlone (2000).
} 
Products are considered as vertical intra-industry trade if imports and exports share just $50 \%$ of their costs. The vertical intra-industry trade are categorized to high and low (VIITH and VIITL), based on whether the quality of exports is higher than that of imports or otherwise, as follows:

If:

$$
\mathrm{PQV}>1.15, \quad \mathrm{VIITH}
$$

The products are categorized as vertical intra-industry trade high and the home country is exporting quality products.

And, if:

$$
\text { PQV }<0.85, \quad \text { VIITL }
$$

The products categorized as vertical intra-industry trade low and the home country is importing quality products.

The aim of this study is to show the range of vertical and horizontal differentiations of intra-industry trade of China with selected developing countries using S and PQV indexes for two time periods, 2000-2004 and 2004-2008.

\section{Data and Results}

Trade data for this study are sourced from the UN COMTRADE database that records imports and exports in quantities and values. To minimize composition problems, we use highly disaggregated data which is compiled at the four-digit standard international trade classification (SITC), Revision 3. The total number of products involved is 34,440 with 683 manufactured products (SITC 5-8) for India, 690 for Indonesia, 679 for the Philippines, 687 for Thailand and 705 products (SITC 5-8) for Malaysia. Product quality changes in intra-industry trade are examined over two time periods, 2000-2004 and 2004-2008. After calculating the S index $(-0.4<S<0.4)$, we focused on positive $S$ index to find the number of products that are beneficial of intra-industry trade for China.

In trade flows of China to India, based on Table 1, the total numbers of products that have significant changes in intra-industry trade for first period are 199. However, the number of positive $S$ shows that only 99 products are beneficial to trade in China. The percentage of the positive $\mathrm{S}$ index is about $49.74 \%$. In the second period, there are 168 products that are categorized as intra-industry trade. The number of positive $S$ in this period is 107; meaning China has gained IIT benefits of $63.7 \%$ in this period. Comparing these two percentages, the situation of China as an exporter to India in 2004-2008 was much better than first period.

For trade between China and Indonesia, the total number of manufactured products (SITC 5-8) that is analysed for each year is 690 for the first period and 507 for the second period. In the first period, total numbers of products that have significant changes in intra-industry trade are 217 , with beneficial trade of 121 products, as supported by the positive S percentage of $55.76 \%$. While in the second period, the total numbers of products that are categorized as intra-industry trade are 280 and the total number of positive $\mathrm{S}$ index are 59. Comparing to the first period, 
Table 1 The results for S Index between China and five Asian countries

\begin{tabular}{|c|c|c|c|c|c|c|}
\hline \multirow{2}{*}{$\begin{array}{l}\text { Time Period } \\
\text { China's } \\
\text { trade partner }\end{array}$} & \multicolumn{3}{|l|}{ 2000-2004 } & \multicolumn{3}{|c|}{ 2004-2008 } \\
\hline & $\begin{array}{l}\text { IIT } \\
\text { (number of } \\
\text { product) }\end{array}$ & $\begin{array}{l}\text { Positive } \mathrm{S} \\
\text { (number of } \\
\text { product) }\end{array}$ & $\begin{array}{l}\text { Percentage } \\
\text { of positive } \\
\mathrm{S}\end{array}$ & $\begin{array}{l}\text { IIT } \\
\text { (number } \\
\text { product) }\end{array}$ & $\begin{array}{l}\text { Positive } \mathrm{S} \\
\text { (number of } \\
\text { product) }\end{array}$ & $\begin{array}{l}\text { Percentage } \\
\text { of positive } \\
\mathrm{S}\end{array}$ \\
\hline India & 199 & 99 & 49.74 & 168 & 107 & 63.7 \\
\hline Indonesia & 217 & 121 & 55.76 & 280 & 59 & 21.07 \\
\hline Thailand & 383 & 167 & 43.6 & 210 & 120 & 57.14 \\
\hline $\begin{array}{l}\text { The } \\
\text { Philippines }\end{array}$ & 252 & 140 & 55.56 & 208 & 124 & 59.61 \\
\hline Malaysia & 253 & 141 & 55.73 & 216 & 137 & 63.42 \\
\hline
\end{tabular}

Calculated from the UN COMTRADE using "S" index. The IIT represents the total number of products that have experienced significant changes in matched trade for the time periods, based on the $\mathrm{S}$ index $(-0.4<\mathrm{S}<0.4)$

the percentage of positive $\mathrm{S}$ has significantly decreased to $21.07 \%$. Analysis for trade flows from China to Thailand involved 687 and 698 manufactured products for the first and second periods, with total number of IIT at 383 and 210, respectively. Meanwhile, the total number of positive $S$ index in the first period is 167 or $43.6 \%$, and 120 or $57.14 \%$ for the second period. Results show that China has significantly improved in export quality during these two periods.

As for Chinese trade with the Philippines, the total number of manufactured products (SITC 5-8) analysed in this study are 679 and 697, for the first and second periods. As shown in Table 1, the total numbers of products that have significant changes in intra-industry trade for the first period are 252, while the total number of positive $\mathrm{S}$ shows that just for 140 products, which is $55.56 \%$, is beneficial of trade towards China. The total numbers of products that are categorized as intra-industry trade in the second period are 208. The total number of positive $S$ in this period are 124 products, implying that China as a quality exporter for $59.61 \%$ of total products in this period. Comparing these two percentages, the situation of China as a quality exporter to the Philippines in 2004-2008 have improved since the first period.

Trade flows between China and Malaysia are similar to that with India and Thailand. There are evidences of improving export quality during these two periods. The total numbers of products that are analysed for each year are approximately 705 manufactured products (SITC 5-8) for both periods. In the first period, the total numbers of products that have significant changes in intra-industry trade are 253 where China gained the benefit of trade from 141 products $(55.73 \%)$. In the second period, the total numbers of products that are categorized as in intra-industry trade are 216 and the total numbers of positive $S$ index are 137. Comparing to the first period, the percentage of the positive $S$ has significantly increased to $63.42 \%$.

Following this, we focused on PQV index to identify similarities and differences in terms of quality in trade flows of China to the selected trade partners. Table 2 and Fig. 1 compare the improvement of product quality. The losses and benefits in intraindustry trade are presented by the extent of product quality improvement over time. 
Table 2 The results for PQV index for trade between China and five Asian countries

\begin{tabular}{|c|c|c|c|c|c|}
\hline \multirow{2}{*}{$\begin{array}{l}\text { Time } \\
\text { period } \\
\text { China's } \\
\text { partner }\end{array}$} & \multicolumn{2}{|l|}{ 2000-2004 } & \multicolumn{2}{|l|}{ 2004-2008 } & \multirow{2}{*}{$\begin{array}{l}\text { Growth of high } \\
\text { quality products (\%) }\end{array}$} \\
\hline & $\begin{array}{l}\text { Low quality } \\
\text { products }(\%)\end{array}$ & $\begin{array}{l}\text { High quality } \\
\text { products }(\%)\end{array}$ & $\begin{array}{l}\text { Low quality } \\
\text { products }(\%)\end{array}$ & $\begin{array}{l}\text { High quality } \\
\text { products }(\%)\end{array}$ & \\
\hline India & 41.02 & 12.82 & 44.44 & 7.40 & -42.28 \\
\hline Indonesia & 42.85 & 9.89 & 27.27 & 9.09 & -8.08 \\
\hline Malaysia & 46.71 & 7.30 & 41.93 & 9.68 & 32.60 \\
\hline Philippine & 54.25 & 9.57 & 56.09 & 6.02 & -37.09 \\
\hline Thailand & 35.19 & 7.26 & 40.90 & 13.64 & 87.88 \\
\hline
\end{tabular}

Calculated from the UN COMTRADE using PQV index

Each figure is divided into four quadrants: quadrant I represents products that have classified as high vertical intra-industry trade (VIITH) where both PQV indices (for example for 2000 and 2004) are more than 1.15. Quadrant II refers to products that shifted from low vertical intra-industry trade (VIITL) to VIITH, means that the PQV of products for 2000 are lower than 0.85 and the PQV of 2004 are more than 1.15. Quadrant III shows the products that are categorized as VIITL where both PQV indices are less than 0.85, and, Quadrant IV represents products that have shifted from VIITH to VIITL where the PQV of products for 2000 are more than 1.15 and the PQV of 2004 are more lower than $0.85 .^{3}$

Results show that percentage of low quality products in both periods is significantly higher than high quality products for all countries. Among the five selected countries, the highest percentage refers to the Philippines with a $56.09 \%$ change between the two study periods. It is also noted that the percentage of low quality products for Thailand, Philippine and India have increased in second period.

A key finding from this study is that two trade partners with highest product quality are Thailand and Malaysia. Both countries show positive percentage of growth for high quality products at 87.88 and $32.6 \%$, respectively. In Thailand, the percentage of high quality products has increased from $7.26 \%$ in the first period to $13.64 \%$ in the second period. It is not surprising since Thailand is the largest importer of high quality goods compared to the rest of the sample, with an increasing export value of over $\$ 105$ billion worth of goods and services annually ${ }^{4}$ including cars, computers and electrical appliances. Thailand is also recently ranked as the fourth richest nation according to GDP per capita in South East Asia, after Singapore, Brunei and Malaysia. Demand for high quality goods and services are also supported by the thriving tourism industry which constitutes about 6 per cent of the economy in Thailand. Whereas international trade plays bigger role in Malaysia as it is one of the world's largest exporters of semiconductor components and devices, electrical goods, solar panels, and information and communication technology products, ${ }^{5}$ which made Malaysia as the second largest quality importers

\footnotetext{
3 The nomination of quadrants are based on Cartesian's quadrant in Mathematics.

${ }^{4}$ CIA World Factbook Thailand.

5 http://www.State.gov (2010).
} 
a

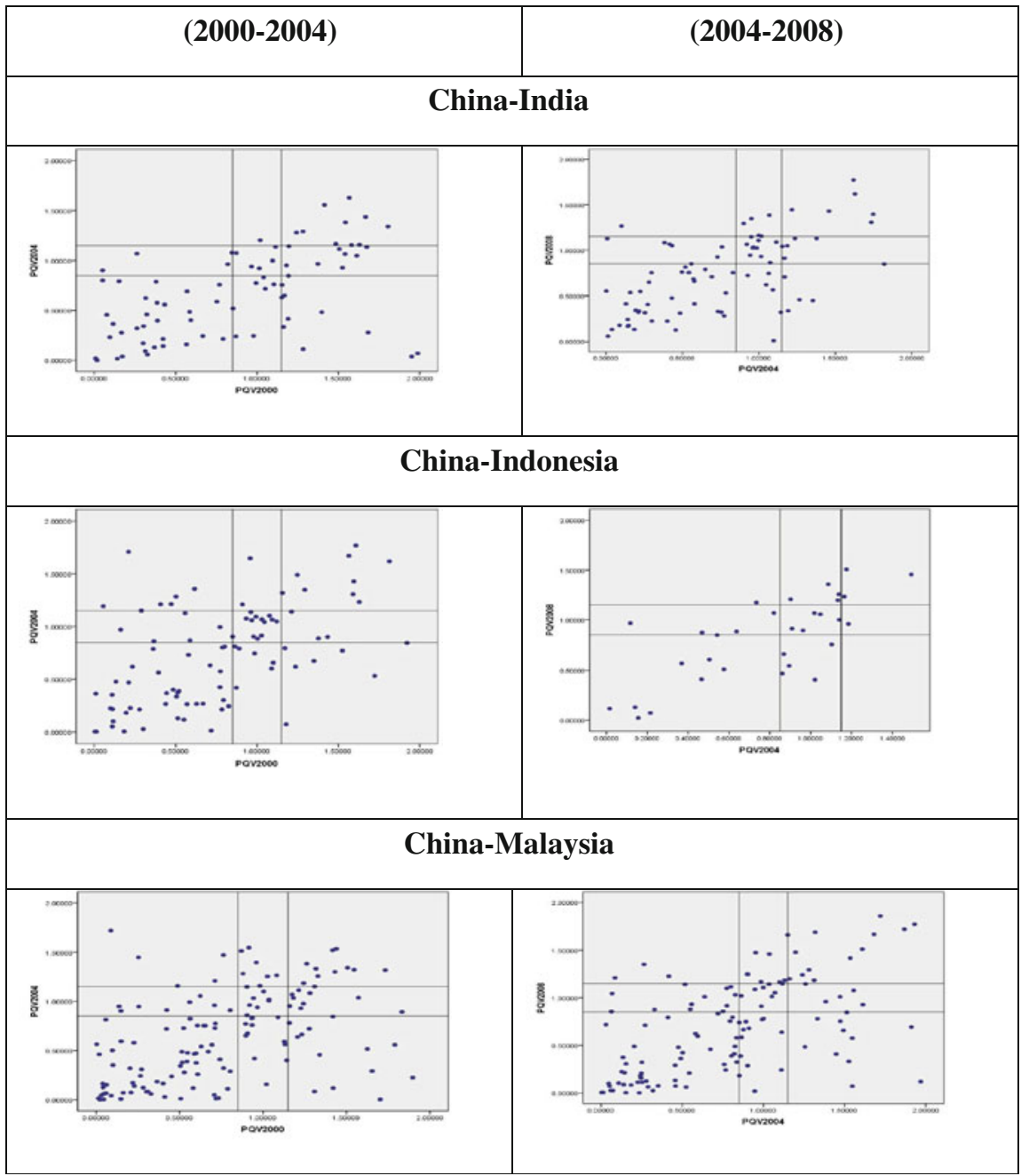

Fig. 1 a PQV index, trade between China and India, Indonesia and Malaysia. b PQV index, trade between China and Philippines and Thailand. Note: Calculated by authors based on database from UN COMTRADE. Key: Products that fall within the T-Zone represent horizontally differentiated goods (HIIT), Quadrant I represents products that have remained as VIITH, Quadrant II represents products that shifted from VIITL to VIITH, Quadrant III represents products that have remained as VIITL, Quadrant $I V$ represents products that have shifted from VIITH to VIITL

from China among the five selected countries examined in this study. This is further supported by the results of $\mathrm{S}$ index showing the improvement of export quality between China and Malaysia.

Figure 1 shows that $12.82 \%$ of products traded between China and India in first period are categorized as VIITH. This implies that China is exporting quality to India. While for second period, the percentage of VIITH is $7.4 \%$ and the 
b

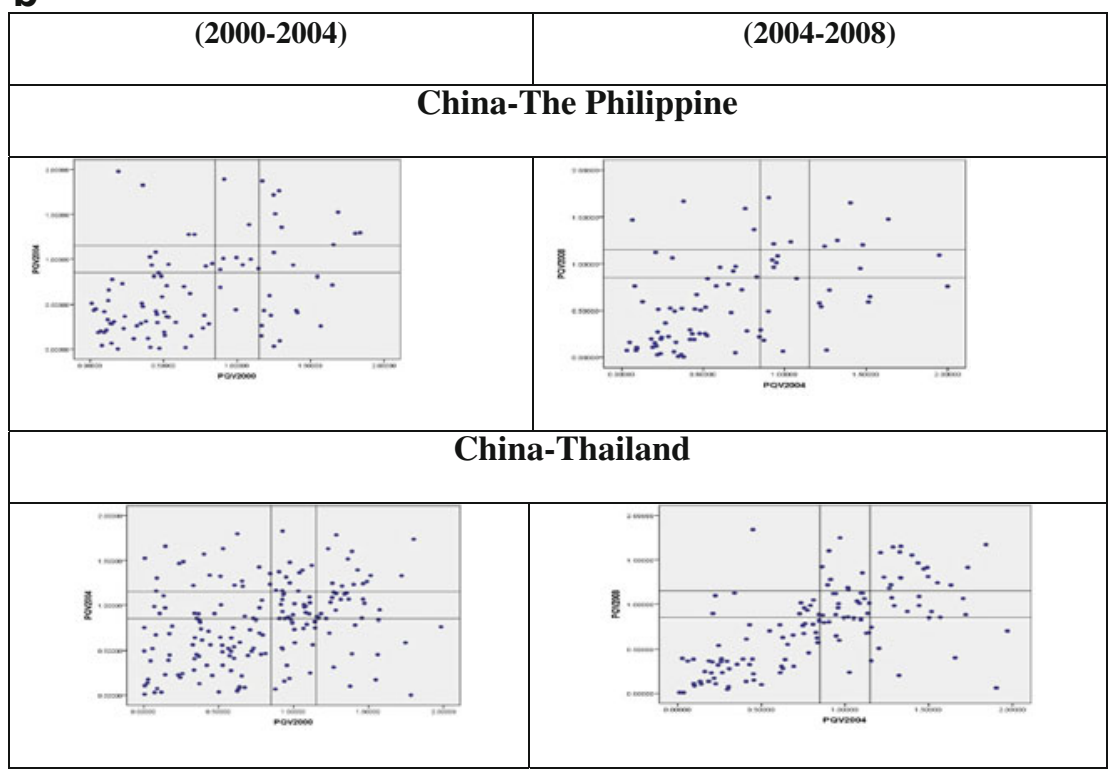

Fig. 1 continued

percentage of growth for high quality products between two periods for India is$42.28 \%$. For Indonesia, $9.89 \%$ of products in the first period are categorised as IITH or high quality products. But for the second period, the percentage of high quality products is $9.09 \%$ with a negative percentage of growth at $8.08 \%$ between the two periods. The PQV index shows that the terms of the quality of exports from China to Indonesia in the first period is much better than the second period. For Malaysia, the percentage of high quality products in first period is $7.3 \%$ and it has increased to $9.68 \%$ in the second period. In contrast, the product quality change for the Philippines shows that the intensity of high quality product for the first period is higher than second period. Since the percentage of high quality products is $9.57 \%$ for first period and $6.02 \%$ for second period, this leads to a negative growth of $-37.09 \%$.

\section{Conclusion}

This study employs a mathematical and graphical method to identify product quality improvement for trade flows between China and five selected Asian countries namely, India, Malaysia, Thailand, the Philippines and Indonesia during two time periods of 2000-2004 and 2004-2008. The results suggest that Malaysia has the highest benefits of intra-industry trade with China with percentage of positive $\mathrm{S}$ in both periods exceeding $50 \%$. The Philippines and India come closely in second and third places. In the case of Thailand, product quality improvement is clearly evident 
in the second period. Based on the percentage of growth of high quality product, Thailand has $87.88 \%$ growth. Since the total number of IIT in Thailand is also highest for both periods among the five countries, it can be a prospective partner choice in trading for China. The most important subsector of industry of Thailand is manufacturing (with $34.5 \%$ of Thailand's GDP in 2004) where it is a centre of automobile manufacturing for the Association of Southeast Asian Nations (ASEAN) market. ${ }^{6}$ On the other hand, with "zero tariffs" preferential policies related to the China-ASEAN Free Trade Area (CAFTA) ${ }^{7}$ that can effectively improve the trade between China and Thailand, it is worth for China to focus on Thailand as a significant high quality products importer.

The opposite holds true in the case of India, Indonesia and the Philippines, where negative percentage of growth means that the export quality in the second period is lower. In recent period, China may have preferred to export more low quality products to India and the Philippines, due to high degree of population growth rate in these countries which creates demand for more imported low quality products from labour intensive China.

\begin{tabular}{lll}
\hline M COMTRADE database & Imports of China from its five trade partners & UN \\
UVX COMTRADE database & Unit value of export (value per quantity) for China & UN \\
UVM COMTRADE database & Unit value of import (value per quantity) for China & UN \\
HIIT COMTRADE database & Horizontal intra-industry trade & UN \\
VIITH COMTRADE database & Vertical intra-industry trade, high & UN \\
VIITL COMTRADE database & Vertical intra-industry trade, low & UN \\
\hline
\end{tabular}

\section{References}

Alchian AA, Allen WR (1964) University Economics, 3rd edn. Wadsworth Publishing Company, Belmont California

Alvarez R, Claro S (2007) On the sources of Chinas export growth, Working Papers Central Bank of Chile No. 426

Azhar AKM, Elliott RJR (2003) On the measurement of trade-induced adjustment. Rev World Econ 139(3):419-439

Azhar AKM, Elliott RJR (2006) On the measurement of product quality in intra-industry trade. Rev World Econ 142(3):476-495

Chiarlone S (2000) Evidence of product differentiation and relative quality in Italian trade, CESPRI Working Papers, No. 114, Centre for Research on Innovation and Internationalization, University Bocconi, Milano, Italy

Devadason E (2008a) China and India in world trade: are the Asia giants a threat to Malaysia? Global Econ Rev 37(4):447-467

Devadason E (2008b) China-India trade relations: new opportunities for cooperation, ICS Working Paper, No. 14

Falvey R (1981) Commercial policy and intra-industry trade. J Intern Econ 11(4):495-511

Falvey RE, Kierzkowski H (1987) Product quality, intra-industry trade and imperfect competition. In: Kierzkowski $\mathrm{H}$ (ed) Protection and competition in international trade. Blackwell, Oxford

\footnotetext{
${ }^{6}$ For example the automakers of Toyota and Ford are active in Thailand.

7 China-ASEAN Expo Secretariat.
} 
Feenstra RC (2004) Advanced international trade: theory and evidence. Princeton University, Princeton Feenstra R, Romalis J (2006) A model of trade with quality choice. University of California, Mimeo, USA

Flam H, Helpman E (1987) Vertical product differentiation and north-south trade. Am Econ Rev 77(5): $810-822$

Fontagné L, Freudenberg M (1997) Intra-industry trade: methodological issues reconsidered. CEPII working paper, No. 97/02

Greenaway D, Hine RC, Milner C et al (1994) Country-specific factors and the pattern of horizontal and vertical intra-industry trade in the UK. Rev World Econ 130(1):77-100

Hallak JC (2006) Product quality and the direction of trade. J Intern Econ 68(1):238-265

Hallak JC, Schott PK (2008) Estimating cross-country differences in product quality. NBER Working, Paper No. 13807

Helble MC, Okubo T (2008) Heterogeneous quality firms and trade costs. World Bank Policy Research Working Paper, No. 4550

Hummels D, Klemow PJ (2005) The variety and quality of a Nation's exports. Am Econ Rev 95(3): 704-723

Hummels D, Skiba A (2004) Shipping the good apples out: an empirical confirmation of the AlchianAllen conjecture. J Political Econ 112(6):1384-1402

Khandelwal A (2010) The long and short of quality ladders. Rev Econ Stud 77(4):1450-1476

Linder S (1961) An essay on trade and transformation. Almqvist and Wiksells, Stockholm

Murphy K, Shleifer A (1997) Quality and trade. J Dev Econ 53:1-15

Romalis J (2004) Factor proportions and the structure of commodity trade. Am Econ Rev 94(1):67-97

Schott PK (2004) A cross-product versus within-product specialization in international trade. Q J Econ 119(2):647-678

Stockey N (1991) The volume and composition of trade between rich and poor countries. Rev Econ Stud 58:63-80 